\title{
STRATEGIC TA'AWUN AND FASTABIQUL KHAIRAT PARTNERSHIPS FOR SUSTAINABLE COMPETITIVE ADVANTAGE AMONG SMALL AND MEDIUM ENTERPRISES IN THE MUSLIM WORLD
}

\author{
Suhaimi Mhd. Sarif \\ Kulliyyah of Economics and Management Science, International Islamic \\ University Malaysia, Jalan Gombak, 53100 Kuala Lumpur, Malaysia \\ Email: suhaimims@iium.edu.my
}

Published online: 20 March 2019

To cite this article: Mhd. Sarif, S. (2019). Strategic ta'awun and fastabiqul khairat partnerships for sustainable competitive advantage among small and medium enterprises in the Muslim world. Asian Academy of Management Journal, 24(Supp. 1), 125-139. https://doi.org/10.21315/aamj2019.24.s1.9

To link to this article: https://doi.org/10.21315/aamj2019.24.s1.9

\begin{abstract}
Strategic ta'awun (cooperation) and fastabiqul khairat (competing for goodness) are two partnership concepts from Islamic perspectives to enable for sustainable competitive advantage with spiritual synergy. The spiritual synergy rooted in the reciprocal norms, motivation, and determination of the operators in making successful entrepreneurial ventures not only for profitability, but for humanity and environmental benefits. This research explores the effects of strategic ta'awun and fastabiqul khairat partnerships among small and medium enterprises (SMES) in the Muslim world to attain and sustain competitive advantage. Strategic ta'awun and fastabiqul khairat are part of the Islamic teachings practiced by Muslim society along with obligatory deeds such as prayers, zakat, and hajj. This study postulates that the spiritual reciprocal power in strategic ta'awun enables for unity and synergy among SMEs in Muslim world. Likewise, the reciprocal power of fastabiqul khairat among SMEs enables Muslim society to venture into model of entrepreneurial, urbanised, and sustainable society. The study interviewed five key SMEs owners representing different geographical locations (Southeast Asia, South Asia, Middle East Asia, North America, and Europe). Indeed, the informants argued that the spiritual reciprocal norm in strategic ta'awun occurred through collaboration and partnerships among SMEs for goodness (fastabiqul khairat) in terms of sharing of expertise, contacts, and commercial projects. This situation allows them to strengthen their competitive
\end{abstract}

(C) Asian Academy of Management and Penerbit Universiti Sains Malaysia, 2019. This work is licensed under the terms of the Creative Commons Attribution (CC BY) (http://creativecommons. org/licenses/by/4.0/). 
advantages in competing with consortium of competitors from different regions. The study suggests the future research to employ case study method for more contextual insights.

Keywords: ta'awun, fastabiqul khairat, sustainable competitive advantage, small and medium enterprises (SMEs), Muslim world

\section{INTRODUCTION}

In recent years, strategic cooperation for the world's sustainability has become an important agenda in the business world apart from the usual competition in the free market. With globalisation, stiff competition has created uncertainty, disorder, and competitive disadvantage in human society (Filatotchev, Su, \& Bruton, 2017; Leonidou, Leonidou, Fotiadis, \& Aykol, 2015; Martin \& Javalgi, 2016). The unhealthy, imbalanced, and uncivilised competition has jeopardised human civilisation and environmental sustainability (Martin \& Javalgi, 2016; Leonidou et al., 2015). As such, humanising the business world with soul, mind, and sense of human is essential.

Nobody wants harm, disaster, and disorder in the human civilisation. Everyone attempts at the best level to offer value to the people and the world including the business world. The spirit of giving and taking on reciprocal basis allows for more offering of benefits (Filatotchev et al., 2017; Martin \& Javalgi, 2016). Moving forward with goodness and competing to offer goodness are sustainable for human civilisation (Hunt \& Morgan, 1995; Narver, Slater, \& MacLachlan, 2004). Thus, competing to offer goodness becomes priority in business decisions.

Human is always the subject in the market despite the emphasis on the production, distribution, and consolidation of wealth of the nation. The humanising of human agenda is necessary after bad consequences to the environment, people, and the economy (Richardson, 2014). Indeed, the larger community of human loves stability, harmony and peace, while the minority opposed to the love and caring society (Hunter, 2012; Redzuan, Rahman, \& Aidid, 2009; Rosly \& Affandi Abu Bakar, 2003).

Naturally, human loves to cooperate on mutual basis (ta'awun) in making good contribution to the society (Hunter, 2012; Redzuan et al., 2009; Richardson, 2014; Rosly \& Affandi Abu Bakar, 2003). In the absence of ta'awun, greediness, selfish, and unethical practices become the driver of the business (Redzuan et al., 2009). Strategic cooperation (ta'awun) allows for priority in determining the ways and means to serve humanity for better goodness (khairat), civilisation, and sustainability. 
This study explores the effects of strategic ta'awun (cooperation) and fastabiqul khairat (competing for goodness) partnerships among small and medium enterprises (SMEs) in the Muslim world for sustainable competitive advantage. Ta'awun and fastabiqul khairat have been the driver for balanced, entrepreneurial, and holistic socio-economic life. The power of ta'awun enables for unity and synergy among SMEs in the Muslim world. Likewise, the power of fastabiqul khairat enables SMEs into entrepreneurial, urbanised, and sustainable situation.

The study is organised into several parts. The first part provides critical literature review on the strategic ta'awun and its effects. The second part comprises the research design and methodology. Then, the study presents the results, incorporates discussion, and offers recommendation for future studies.

\section{LITERATURE REVIEW}

This study argues strategic cooperation (ta'awun) encourages healthy competition (fastabiq) in offering goodness (al-khairat) on sustainable basis among SMEs in the Muslim world. This study critically reviews literature that are related to the phenomenon, concept, idea, constructs, and variables on strategic ta'awun, fastabiqul khairat, and SMEs that drive the market and create sustainable competitive advantages to the world and human civilisation. Figure 1 illustrates key constructs of the study, namely strategic ta'awun (cooperation), competing for goodness (fastabiqul khairat), and sustainable competitive advantage.

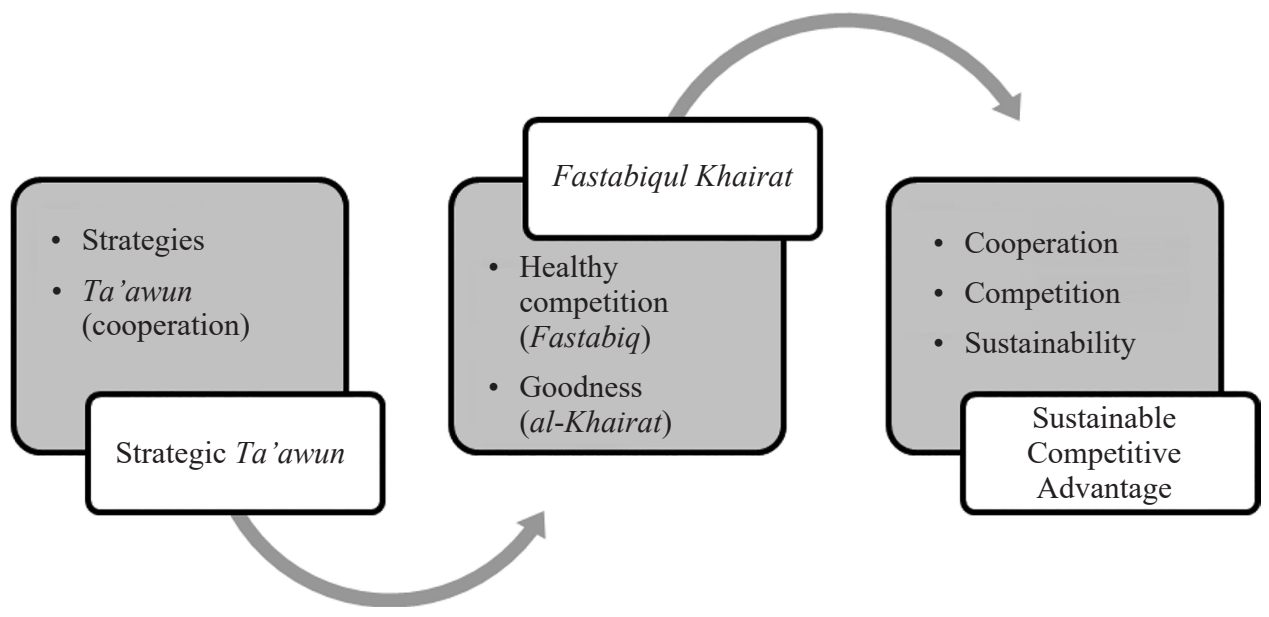

Figure 1. Key constructs of the study 


\section{Competition and Sustainability}

Competition is healthy in the free market economy under the compassionate and humanising value. Nobody wants the world to be unhealthy, chaotic, and uncertain. Everyone attempts their best level to offer good value to the market even though under a competitive manner. According to Redzuan et al. (2009), good business always results in good consequences to many people. Everyone is helping to make the world a good place to live (Sonenshein, Nault, \& Obodaru, 2017). The business of making goodness, peace, and tranquillity is always sustainable.

Sustainability and competition are workable for the betterment of human society. When the business is very competitive, it allows for continuous creativity and innovation in offering superior value to the market. This is essential for any business to create and sustain competitive advantage (Redzuan et al., 2009; Rosly \& Affandi Abu Bakar, 2003; Song, Woo, \& Rao, 2007). When the market is too competitive, it leaves very little room for creativity and innovation (Redzuan et al., 2009; Sonenshein et al., 2017) for companies to create competitive advantage. In response to this stiff competitive situation, every business needs to cooperate with other businesses.

Sustainability and cooperation are strategic factors in making the business world continue to prosper and excel. Sustainability allows for continuous offering of value to the market, which is good for the society. Cooperation enables value creation on a mass scale (Sonenshein et al., 2017). Competing for goodness is sustainable in the business world regardless of the market size and competitive advantage being pursued (Redzuan et al., 2009; Song et al., 2007; Whelan, 2017). Thus, cooperation in the competitive market leads to cooperating and competing for sustainable competitive advantage.

Cooperation while competing is a sustainable way of driving the market economy with more social responsibility and accountability. Lozano (2015) argued that the competitive nature of the market should not neglect the basic responsibility of people to work on their business with a holistic, comprehensive, and balanced view. Being charitable to the market and the stakeholders is part of the social responsibility for betterment of the society (Godfrey, 2005). Indeed, sustainability has always been a perpetual interest of the market participants. Based on the discussion, this study postulates that sustainability in gaining competitive advantage is influenced by cooperation (ta'awun), goodness (khairat), and economic orientation. 


\section{Strategic Ta'awun}

The nature of this study is multidisciplinary. It integrates Islamic economics with strategic management, organisational behaviour, and political economics. This study defines ta'awun from Islamic economics as a manifestation of brotherhood (ukhuwwah) (Khan, 1999). It is an expression of love, care, responsibility, and accountability that unites the people regardless of their differences. Ukhuwwah is authentic and normative. According to Ahmed Haj Ali, Noordin, and Achour (2018), ta'awun is simply the mutual cooperation in executing religious obligation. There is interaction process or exchange in performing religious obligation through mutual cooperation.

There are some theories that can explain the mutual cooperation in the interaction process or exchange. From organisational behaviour perspectives, the mutual cooperation to implement obligation can be explained by exchanged theories, namely Social Exchange Theory (SET) (Blau, 1964) and Leader-Member Exchange (LMX) Theory (Graen \& Cashman, 1975). In SET, Blau (1964) argued that in exchange or interaction among people, at least two requirements are involved, namely trust and personal obligation. Trust is outcome of continuous demonstration of integrity, ethical, responsibility, and accountability in all transaction, exchange, and interaction. As for personal obligation, it is a result of willingness and readiness of individual to make the human society a better place to live in peacefully.

In the context of organisations, the quality of the exchange and relationship can be explained by LMX theory due to reciprocity norm (Gouldner, 1960). Leader influences the interaction of transaction among people for mutual benefit. For ta' awun from the Islamic perspective, the exchange requires spirituality dimension into the reciprocity norm (Choudhury, 2010). According to Beekun (1997), the ta'awun spiritual dimension in human develops over four values, namely goodness (khayr), truth (haqq), righteousness (birr), and piety (taqwa). As for Khalifa (2001), the role of piety (taqwa) consolidates the spiritual dimension of mutual cooperation in seeking maximum benefit. Thus, ta'awun is not just Islamic teaching for specific worship (ibadah), but it is a norm that integrates rules, obligations, values, manners, and practices to assure trustworthiness, integrity, and justice in human relationships and human civilisation. In a strategic mutual cooperation, the reciprocity requires cohesive role in kindness and cooperation behaviour in the exchange (Soler, 2012). The exchange is driven by shared meaning and common goals of the organisation. 
As for Blau (1964), there are two elements in the exchange relationships or interaction process, namely reciprocal and negotiated. The exchange relationships occur in social and economic dimensions with the obligations and expectations. The high-quality exchange or interaction process has gone through rigorous accumulated interactions to develop reciprocal in the trust and personal obligations (Cropanzano \& Mitchell, 2005).

The SET explains reciprocal in developing trust by committed to personal obligations. However, the reciprocal is merely "trusting others" and making "personal obligations". Most organisations are very much concerned about a few factors. Firstly, the reciprocal of trust and personal obligation are not adequately explained regarding the degree in the expectation of reciprocity (Rotenberg \& Mann, 1986). In other words, SET has not measured the expectation in the interaction for mutual benefit among the people in the relationship and interaction (Cropanzano \& Mitchell, 2005). Secondly, SET has not explained the influence of obligation to reciprocate (Korsgaard, Meglino, Lester, \& Jeong, 2010). Next, SET has not set the obligation of interaction process (Mitchell, Cropanzano, \& Quisenberry, 2012). Fourthly, SET has not measured the reciprocity degree on how much it could enrich psychological well-being to sustain the interaction process (Thomas, 2010). Finally, SET has not been able to determine the level of well-being in the reciprocity (Buunk, Doosje, Jans, \& Hopstaken, 1993).

The concerns of reciprocal of trust and personal obligation for mutual benefit are essential. In the context of organisations, LMX can provide the focus on the leader for measuring the relationship. Leaders deal with their exchange relationships with each subordinate differently (Green \& Liden, 1980). This interaction leads to mutual relationship for mutual benefit. Indeed, the degree of reciprocal of trust and personal obligation are developed over mutual relationships in workplace with the organisational support (Kam et al., 2014). Nevertheless, such mutual relationship is without the concern of spiritual, soul, and emotional intelligence. Such exclusion will not only devalue human to be powerless but also lead to injustice in human relations (Byrd, 2014).

Strategic ta'awun or high performing cooperation among firms enables them to drive value for the market. Rosly and Affandi Abu Bakar (2003) argued that in the context of for profit entities, ta'awun or mutual cooperation drives strong and sustainable relationship. Indeed, there are various factors contributing to strategic ta'awun, namely the strong bond among the participants ( $u k h u w w a h)$, the concern of driving value in competitive manner (fastabiqul khairat), and the dynamic capability (Slater \& Narver, 1994). 
Ta'awun and fastabiqul khairat are complementary and reciprocal in nature. The

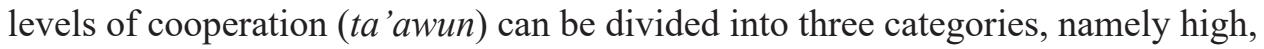
moderate, and low ta'awun. According to Rosly and Affandi Abu Bakar (2003), cooperation is strategic when it addresses on strategic advantages (al-birr) and piety (al-taqwa). Ta'awun is not counted in the activities that contributed to sinful (al-ithm) and enormity (al-udwan). Likewise, competing for goodness (fastabiqul khairat) also can be divided into three levels, namely, broad, moderate, and focused fastabiqul khairat.

\section{Entrepreneurial Setting}

A competitive business environment offers dynamism that can be beneficial to stakeholders. Indeed, competition moderates business performance (Martin \& Javalgi, 2016) into higher level of achievement. Thus, the market needs innovation for growth and survival (Hurley \& Hult, 1998). Innovation has entrepreneurial element to trigger for improvement, modification, and new products or services. Newness is necessary (Atuahene-Gima, 1996) for sustainability. In any degree of innovation, it requires entrepreneurial mind reorienting the market and product for better performance (Matsuno, Mentzer, \& Özsomer, 2002). The reinforcement of entrepreneurial mindset contributes to the reorientation of the market and product with social responsibility, ethical, and sustainability (Matsuno et al., 2002). With the market dynamic capability, competitive advantage and market positioning enable for enhancement of capabilities and dynamism (Grewal \& Tansuhaj, 2001).

Since this study argues that there are effects of strategic ta'awun on sustainable, entrepreneurial, and urbanised smart society, the conceptual framework of the study postulates the key elements, drivers, and constructs of strategic ta'awun into the sustainability forces and drivers. Figure 2 illustrates the conceptual framework of this study.

\section{METHODOLOGY}

This study uses qualitative research due to the objective of the study, i.e., to explore the effects of strategic ta' awun (cooperation) and fastabiqul khairat (competing for goodness) in the collaborative relationship and partnerships among SMEs in the Muslim world for sustainable competitive advantage. Qualitative research allows rich understanding of the context. 


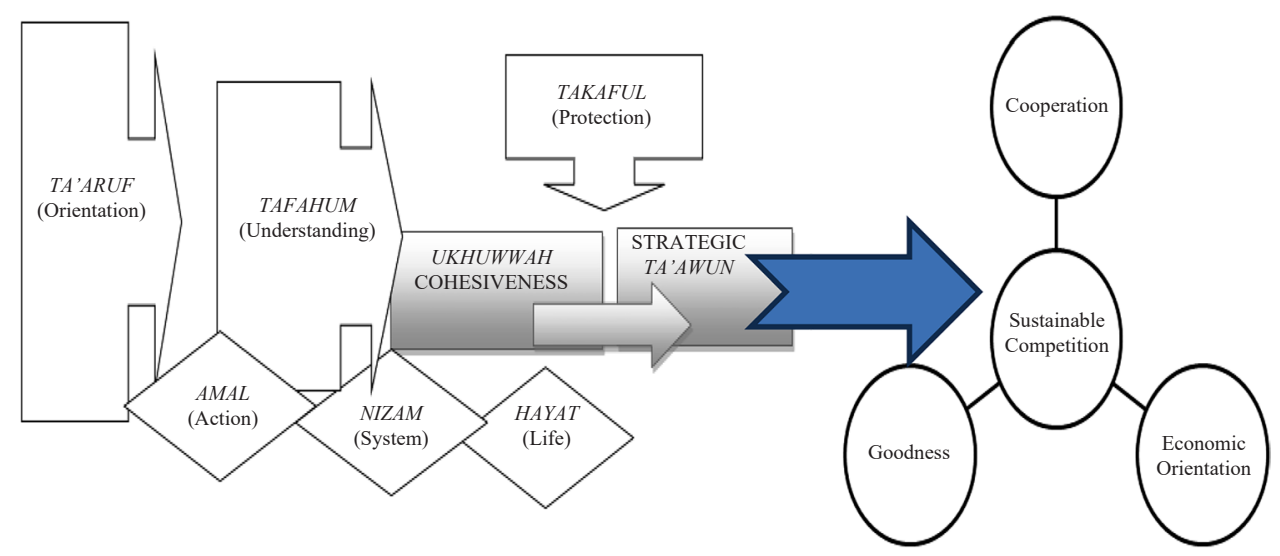

Figure 2. Conceptual framework of the study

In this study, the effects of strategic ta'awun and fastabiqul khairat are contextual and pragmatic. The understanding of context, event, individual, group, and phenomenon is appropriate with qualitative research (Symon, Cassell, \& Johnson, 2018; Whittemore, Chase, \& Mandle, 2001). In the meantime, qualitative research is acceptable into academic and non-academic fields due to its procedure and protocol to reliability, validity, trustworthiness, and transferability of the results (Whittemore et al., 2001). Prior to the actual interview, this study has conducted pilot study with experts in the field to assure the validity and reliability of the interview questions. Some changes were made after obtaining the results of the pilot study.

The study interviewed five key SMEs owners representing different geographical locations (Southeast Asia, South Asia, Middle East Asia, North America, and Europe). The participants were selected based on the recommendation of a few office bearers from World Academy of Islamic Management (WAIM) who used to collaborate with them in research, training, and consultancy. Prior to the interview, the study had obtained informed consent from the participants. Each interview consumed between 30 to 50 minutes with note-taking. The study transcribed all interview notes into transcript and was later verified by the participants. Then, the study approached independent researchers who are familiar with the subject matter to validate the results of the interview. This was done to ensure validity of interpretation, credibility of the feedback, the trustworthiness of the feedback and interpretation, and transferability of the study in the future. 
The study also assured the participants of the study that all the instruments, notes, and documents signed by the participants and independent researchers are kept in the registered storage under the surveillance of institutional security forces. The safety of the data is essential to protect the privacy and confidentiality of the data.

\section{RESULTS}

The results are based on five key SMEs owners who came from different geographical locations (Southeast Asia, South Asia, Middle East Asia, North America, and Europe) obtained through personal interview. All the informants involved directly in SMEs at various countries through various mechanisms, particularly dealing in the Muslim world.

The study analysed the feedback of informants with content analysis manually and verified by experts for validity, reliability, consistency, and trustworthiness. According to the informants, there were past and on-going strategic cooperation among SMEs at national, regional, and international level for the sake of survival in the competitive market. Indeed, Muslim and non-Muslim SME owners work closely to position in the competitive market. For example, one of the informants, SMEO 1, said:

We have no time to check on religious background of our counterparts in small and medium businesses. After all, the entire supply chain is in the hands of non-Muslim suppliers, wholesalers, and distributors. Muslim and non-Muslim owners of small and medium enterprises have no choice but to work together.

Apart from survival of the business, the participants also argued that innovation and creativity are equally important for survival and growth. Even in small business, with many competitors, survival is essential. In this regard, for example, SMEO 2 mentioned:

Small business is small in capital, resource, capability, and so on. There are many small businesses in the market selling the same products or offering the same services. We have no choice but to be creative in appealing our customers. Small change that we offered to our customers made them happy. 
In referring to the survival of the business and at the same time making some contribution to the society, small businesses had to go through and capitalised all kinds of opportunities into their bottom line. For example, SMEO 3 said:

Small businesses like us have no choice but to follow the trend in the market. Yes, our size is small in terms of capital, market share, and market positioning. Being first mover is very unlikely due to our resources. Being late mover is always being left behind and we have to work harder to get some customers who are still in the market.

SMEO 3 has been providing services to many immigrant service firms in Klang Valley for many years. There is a significant level of cooperation among the immigrant SMEs. SMEO 3 said:

Arab immigrant entrepreneurs work very closely whether in the same or different businesses. They are helping among them. Similarly, the Indonesia immigrant business owners, they just work around the clock very closely. The spirit of helping and complementing is very high. They are willing to advance some capital to their friends who have strong passion in business.

SMEO 4 contended that SMEs have been cooperating among them for various reasons. However, when a few SMEs combined into collaboration, they are still far behind from the bigger enterprises. SMEO 4 said:

SMEs must work together as one big team to face the giant among foreign enterprises. But, our togetherness is just for a short while. We could not sustain our collaboration due to our own survival. Sometimes to depend on the collaboration for business jobs will be time consuming and tedious.

Ta'awun and fastabiqul khairat are always started from home. In the presence of ta'awun and fastabiqul khairat, SMEs are motivated to produce more outcomes for many people. Any cooperation has tendency to produce sustainable outcomes. However, in this current context of economy, politics, and social, more stringent law are being introduced and applied. SMEO 5 said:

When people are ready to work together for the betterment of the society and business, they will work very hard to ensure the success. And also they have to sustain leadership and good culture. 


\section{DISCUSSION}

The interview results highlighted a few things about the effects of strategic ta'awun and fastabiqul khairat in the collaborative relationships and partnerships among SMEs in the Muslim world for sustainable competitive advantage.

Firstly, the informants argued that strategic ta'awun and fastabiqul khairat in the collaborative reciprocal relationships and partnerships with spirituality and values among them as SMEs from different regions are for the sake of survival in the competitive market. In fact, Muslim and non-Muslim SME owners work closely to position in the competitive market.

Secondly, the orientation of strategic ta'awun and fastabiqul khairat was in the collaborative relationships and partnerships among them only at the entry level, and conservative and traditional modes of competition instead of cooperation. Indeed, the competition among SMEs is very stiff and difficult for them to survive in the business. The main reason was due to lack of resources and lack of capability for SMEs in the Muslim world to create and sustain competitive advantage. In fact, even if the business is similar, there is no willingness to cooperate for better capability.

Thirdly, strategic ta'awun and fastabiqul khairat in the collaborative relationships and partnerships among them have been limited into trivial and insignificant impact to the market. Even in the collaboration among a few SMEs, they are still far behind from the bigger enterprises.

Finally, strategic ta'awun and fastabiqul khairat in the collaborative relationships and partnerships among them have been in the context of family or home-based among SMEs. The home-based matters are related to building competency, having good attitude in business, and character-building of resilient entrepreneurs.

Indeed, the effects of strategic ta'awun and fastabiqul khairat in the collaborative relationships and partnerships among SMEs in the Muslim world for sustainable competitive advantage are into: (a) increasing competitiveness and survival in the competitive market; (b) gradual and steady mode of making cooperation as basis for building competitiveness; (c) fine tuning into strategic niche within the main stream competitive market; and (d) family-oriented cooperation and competition. These factors allow for innovative and creative SMEs not just for survival but also for sustainable development of nation (Atuahene-Gima, 1996; Matsuno et al., 2002). In any degree of innovation, it requires entrepreneurial mind reorienting the market and product for better performance. 


\section{CONCLUSION}

This research concludes that the effects of strategic ta'awun (cooperation) and fastabiqul khairat (competing for goodness) in the collaboration partnerships among SMEs in the Muslim world are phenomenal for the enterprises to sustain competitive advantage. Ta'awun and fastabiqul khairat become just enablers for the life of Muslim society through obligatory deeds such as prayers, zakat, and hajj if these enablers were not capitalised with the opportunities in the market. The power of ta'awun brings unity and synergy among SMEs. Likewise, the power of fastabiqul khairat among SMEs could make them resume a role model of entrepreneurial, urbanised, and sustainable society.

Indeed, strategic ta'awun in the forms of collaboration and partnership among SMEs led to promoting and championing for goodness (fastabiqul khairat). This situation allows them to strengthen their competitive advantages in competing with consortium of competitors from different regions.

\section{ACKNOWLEDGEMENTS}

The author would like to acknowledge the research funding from the Ministry of Education Malaysia through the Fundamental Research Grant Scheme (FGRS 13017-0258), research management support from International Islamic University Malaysia, and all parties involved in this research.

\section{REFERENCES}

Ahmed Haj Ali, A.R., Noordin, K., \& Achour, M. (2018). The Islamic approach of obligations in mutual relations between employee and employer. International Journal of Ethics and Systems, 34(3), 338-351. https://doi.org/10.1108/ IJOES-12-2017-0227

Atuahene-Gima, K. (1996). Market orientation and innovation. Journal of Business Research, 35(2), 93-103. https://doi.org/10.1016/0148-2963(95)00051-8

Beekun, R.I. (1997). Islamic business ethics. Herndon, VA, USA: International Institute of Islamic Thought (IIIT).

Blau, P. (1964). Power and exchange in social life. New York, NY: John Wiley \& Sons.

Buunk, B.P., Doosje, B.J., Jans, L.G., \& Hopstaken, L.E. (1993). Perceived reciprocity, social support, and stress at work: The role of exchange and communal orientation. Journal of Personality and Social Psychology, 65(4), 801-805. https://doi. org/10.1037/0022-3514.65.4.801 
Byrd, M.Y. (2014). Spirituality and diversity in the workforce. In M.Y. Byrd, \& C.L. Scott (Eds.), Diversity in the workforce: Current issues and emerging trends (pp. 201-217). Abingdon, UK: Routledge. https://doi.org/10.4324/9780203797778

Choudhury, M.A. (2010). The dynamics of the Shari'ah and the world-system. Journal of King Abdulaziz University: Islamic Economics, 23(2), 203-230.

Cropanzano, R., \& Mitchell, M.S. (2005). Social exchange theory: An interdisciplinary review. Journal of Management, 31(6), 874-900. https://doi. org/10.1177/0149206305279602

Filatotchev, I., Su, Z., \& Bruton, G.D. (2017). Market orientation, growth strategy, and firm performance: The moderating effects of external connections. Management and Organization Review, 13(3), 575-601. https://doi.org/10.1017/mor.2016.31 and https://doi.org/10.1017/mor.2017.35 (with addendum).

Godfrey, P.C. (2005). The relationship between corporate philanthropy and shareholder wealth: A risk management perspective. Academy of Management Review, 30(4), 777-798. https://doi.org/10.5465/amr.2005.18378878

Gouldner, A.W. (1960). The norm of reciprocity: A preliminary statement. American Sociological Review, 25(2), 161-178. https://doi.org/10.2307/2092623

Graen, G., \& Cashman, J.F. (1975). A role-making model of leadership in formal organizations: A developmental approach. Leadership Frontiers, 143, 165-168.

Green, S.G., \& Liden, R.C. (1980). Contextual and attributional influences on control decisions. Journal of Applied Psychology, 65(4), 453-457. https://doi. org/10.1037/0021-9010.65.4.453

Grewal, R., \& Tansuhaj, P. (2001). Building organizational capabilities for managing economic crisis: The role of market orientation and strategic flexibility. Journal of Marketing, 65(2), 67-80. https://doi.org/10.1509/jmkg.65.2.67.18259

Hunt, S.D., \& Morgan, R.M. (1995). The comparative advantage theory of competition. The Journal of Marketing, 59(2), 1-15. https://doi.org/10.1177/002224299505900201

Hunter, M.M. (2012). Towards an Islamic business model: A tawhid approach. International Journal of Business and Technopreneurship, 2(1), 121-135.

Hurley, R.F., \& Hult, G.T.M. (1998). Innovation, market orientation, and organizational learning: An integration and empirical examination. The Journal of Marketing, 62(3), 42-54. https://doi.org/10.1177/002224299806200303

Kam, V.D., Niels, A., Onne, J., Gerben, S., Vegt, V.D., \& Janka, S. (2014). The role of vertical conflict in the relationship between leader self-enhancement and leader performance. The Leadership Quarterly, 25(2), 267-281. https://doi.org/ 10.1016/j.leaqua.2013.08.007

Khalifa, A.S. (2001). Towards an Islamic foundation of strategic business management. Selangor: IIUM Press.

Khan, M.A. (1999). Islamic economics: The state of the art. American Journal of Islamic Social Sciences, 16(2), 89-104.

Korsgaard, M.A., Meglino, B.M., Lester, S.W., \& Jeong, S.S. (2010). Paying you back or paying me forward: Understanding rewarded and unrewarded organizational citizenship behaviour. The Journal of Applied Psychology, 95(2), 277-279. https://doi.org/10.1037/a0018137 
Leonidou, L.C., Leonidou, C.N., Fotiadis, T.A., \& Aykol, B. (2015). Dynamic capabilities driving an eco-based advantage and performance in global hotel chains: The moderating effect of international strategy. Tourism Management, 50(October), 268-280. https://doi.org/10.1016/j.tourman.2015.03.005

Lozano, R. (2015). A holistic perspective on corporate sustainability drivers. Corporate Social Responsibility and Environmental Management, 22(1), 32-44. https://doi. org/10.1002/csr.1325

Martin, S.L., \& Javalgi, R.R.G. (2016). Entrepreneurial orientation, marketing capabilities and performance: The moderating role of competitive intensity on Latin American international new ventures. Journal of Business Research, 69(6), 2040-2051. https://doi.org/10.1016/j.jbusres.2015.10.149

Matsuno, K., Mentzer, J.T., \& Özsomer, A. (2002). The effects of entrepreneurial proclivity and market orientation on business performance. Journal of Marketing, 66(3), 18-32. https://doi.org/10.1509/jmkg.66.3.18.18507

Mitchell, M.S., Cropanzano, R.S., \& Quisenberry, D.M. (2012). Social exchange theory, exchange resources, and interpersonal relationships: A modest resolution of theoretical difficulties. In K. Törnblom, \& A. Kazemi (Eds.), Handbook of social resource theory (pp. 99-118). New York, NY: Springer. https://doi.org/ 10.1007/978-1-4614-4175-5_6

Narver, J.C., Slater, S.F., \& MacLachlan, D.L. (2004). Responsive and proactive market orientation and new-product success. Journal of Product Innovation Management, 21(5), 334-347. https://doi.org/10.1111/j.0737-6782.2004.00086.x

Redzuan, H., Rahman, Z.A., \& Aidid, S.S.S.H. (2009). Economic determinants of family Takaful consumption: Evidence from Malaysia. International Review of Business Research Papers, 5(5), 193-211.

Richardson, C. (2014). Firm internationalisation within the Muslim world. Journal of World Business, 49(3), 386-395. https://doi.org/10.1016/j.jwb.2013.07.005

Rosly, S.A., \& Afandi Abu Bakar, M. (2003). Performance of Islamic and mainstream banks in Malaysia. International Journal of Social Economics, 30(12), 12491265. https://doi.org/10.1108/03068290310500652

Rotenberg, K.J., \& Mann, L. (1986). The development of the norm of the reciprocity of selfdisclosure and its function in children's attraction to peers. Child Development, 57(6), 1349-1357. https://doi.org/10.2307/1130414

Slater, S.F., \& Narver, J.C. (1994). Does competitive environment moderate the market orientation-performance relationship? The Journal of Marketing, 58(1), 46-55. https://doi.org/10.1177/002224299405800104

Soler, M. (2012). Costly signaling, ritual and cooperation: Evidence from Candomblé, an Afro-Brazilian religion. Evolution and Human Behavior, 33(4), 346-356. https://doi.org/10.1016/j.evolhumbehav.2011.11.004

Song, Y.I., Woo, W., \& Rao, H.R. (2007). Interorganizational information sharing in the airline industry: An analysis of stock market responses to code-sharing agreements. Information Systems Frontiers, 9(2-3), 309-324. https://doi.org/10.1007/s10796007-9026-7 
Sonenshein, S., Nault, K., \& Obodaru, O. (2017). Competition of a different flavour: How a strategic group identity shapes competition and cooperation. Administrative Science Quarterly, 62(4), 626-656. https://doi.org/10.1177/0001839217704849

Symon, G., Cassell, C., \& Johnson, P. (2018). Evaluative practices in qualitative management research: A critical review. International Journal of Management Reviews, 20(1), 134-154. https://doi.org/10.1111/ijmr.12120

Thomas, P.A. (2010). Is it better to give or to receive? Social support and the well-being of older adults. Journals of Gerontology Series B: Psychological Sciences and Social Sciences, 65(3), 351-357. https://doi.org/10.1093/geronb/gbp113

Whelan, C. (2017). Managing dynamic security networks: Towards the strategic managing of cooperation, coordination and collaboration. Security Journal, 30(1), 310-327. https://doi.org/10.1057/sj.2014.20

Whittemore, R., Chase, S.K., \& Mandle, C.L. (2001). Validity in qualitative research. Qualitative Health Research, 11(4), 522-537. https://doi.org/10.1177/ 104973201129119299 